\title{
Biotechnological methods to improve the quality and safety of milk
}

\author{
G.V. Rodionov, Kh.A. Amerkhanov, O.I. Solovieva, A.P. Olesyuk, and C.S.M. Minero* \\ Moscow Agricultural Academy named after K.A. Timiryazev, Moscow, Russia
}

\begin{abstract}
The foremost task of milk producers and processors is to prolong the shelf life of dairy products. One of the high-tech and innovative ways to address this issue is to suppress the growth of undesirable microorganisms. EMR milk treatment is proposed as one of such promising methods of product exposure in order to reduce the total microbial count, improve the milk's chemical composition, and, ultimately, improve the quality and safety of milk and dairy products. The requirements of regulatory documents for the safety of milk and dairy products prohibit the direct introduction of preservatives into milk. In this regard, it is advisable to look for ways to use preservatives in packaging materials' composition while observing the safety of the packaging itself. The purpose of our study was to identify the effect of electromagnetic treatment and preservatives, both direct application and in the composition of polyethylene packaging, on the physicochemical and microbiological parameters of milk at various storage temperatures. It was established that preservative's introduction into the packaging film did not affect the chemical parameters of milk; the content of lactic acid bacteria in the product after a day of storage in modified polyethylene amounted to $1.4 \times 10^{6} \mathrm{CFU} / \mathrm{cm}^{3}$, while their number amounted $8.1 \times 10^{6} \mathrm{CFU} / \mathrm{cm}^{3}$ when stored in glass packaging.
\end{abstract}

\section{Introduction}

Modern conditions of the dairy market dictate the producers to manufacture only highquality products at minimal costs, which increase economic efficiency. This determines the prospects for further development and requires, in particular, the development of innovative advanced methods and equipment, allowing to preserve the natural milk component composition unchanged, improve its technological performance, parameters of microbiological purity, thereby ensuring the production of high-quality priority dairy products $[9,13,17]$.

In recent years, the most attractive are biotechnological methods of milk processing, including electrical and electrophysical methods of milk and dairy products' production and processing, mainly microwave energy in constant and pulsed modes, infrared radiation, electroactivation, sound vibrations, UV radiation, as well as processing the product with

\footnotetext{
* Corresponding author: salvadorminero8@gmail.com
} 
high pressure, enzyme complexes, etc. [5, 8, 16]. Such innovative ways of product impact contribute to the selective effect on the chemical and microbiological milk composition, change individual parameters and components of milk [16]. The specific chemical bonds of milk are exposed to various fields, which entails a change in milk quality, fermented milk products' properties, mainly such important technological parameters as the moistureretaining capacity of protein coagulums, the fermentation time. This is especially important to consider when producing fermented milk products. The use of such technologies puts the task of guaranteeing the absolute full-value and safety of proteins, lactose, fats, macro- and micronutrient composition and milk vitamins at first. It should be noted that the features of the differentiated effect of such inhibitors as preservatives, electromagnetic treatment on the nature of milk microflora development, the qualitative composition of milk and dairy products have been little studied and are of deep scientific and practical interest.

To process milk and reduce its bacterial load, scientists have developed technological equipment that makes it possible to obtain unconventional energy sources, in particular, by means of microwaves (alternating electromagnetic field of ultra-high frequency), peak waves (electron-beam plasma) and powerful pulsed magnetic fields.

Another innovative approach in raw milk processing is the use of electrochemically activated water for dairy equipment, which has a high redox potential and some anomalous attributes. Technological method of electrochemical water activation can reduce the number of bacteria and viruses by a factor of thousands $[1,8,14]$.

There are methods for processing liquids and fluid products including milk by pulses of an electromagnetic field. The data obtained indicate the effectiveness of short electromagnetic pulses' usage with the aim of a directed change towards improving milk quality and safety indicators $[5,8,17]$.

In addition, a method of processing liquids is used, which is based on the action of electrical impulses having a large inhibitory effect on the cell's genetic material; its control system changes by means of a radiating field and independent electrons formed in the cell of a microorganism as a result of exposure to this electric field [8].

In order to effect milk microorganisms, a method of influencing the quality of milk and dairy products is proposed, which is based on the external exposure on the development of milk microorganisms to electromagnetic pulses of specified parameters. They, in turn, have a selective effect on the growth and development of microorganisms up to complete suppression $[2,3]$. Studies show that changing the impulses' parameters carries an absolute or partial vital activity suppression of bacteria and microscopic milk fungi.

The proposed method makes it possible to stabilize or improve the native qualities of milk and dairy products, such as taste, smell, consistency, as well as increase the shelf life and reduce the specific energy consumption for production processes [12].

Today, there is an acute need for a deep and detailed study of each type of irradiated dairy product, which falls on the table of a wide range of consumers [13, 17, 18]. There is not enough data on the study of electromagnetic radiation on individual milk components, in particular during storage at set temperatures and after exposure to physical and/or chemical factors.

Research by G.V. Rodionov, O.G. Khoruzheva, S.D. Baduanova, E.V. Pronina were devoted to the effect of EM radiation on the physicochemical and microbiological parameters of raw milk $[5,8,9]$. However, no studies have been conducted on changes in storage of individual components of milk and dairy products that are treated with EMR.

Pronina E.V., Olesyuk A.P. have reliably noted an increase in the amount of total and inorganic nitrogen in milk after 20 minutes of exposure to electromagnetic pulses $[5,8]$. The urea content decreased by $0.1 \mathrm{mg} \%$ after EMR. The level of whey and casein proteins in the test samples varied as well. 
In some cases, milk is preserved using special preservatives with the letter "E". The preservation of milk and dairy products is widely used by sterilization and pasteurization, cooling and freezing, drying, adding sugar, and ionizing radiation treatment. The advantages of canned milk are due to high nutrients' concentration and moisture removal from the product, which subsequently provides the ease of transportation and storage duration $[1,4,6]$. The conservative effect of sugar is based on an increase in the osmotic medium pressure being several times higher than the intracellular pressure, which leads to the suspension of the bacterial cell's development. The moisture evaporation technology implies the residue of a minimum amount of water with dissolved sugar crystals in the product, which subsequently turns into a bound state and becomes inaccessible to microorganisms.

According to the requirements of the Technical Regulations of the CU and GOST, the direct introduction of preservatives and preservative agents into drinking milk and dairy products is not allowed; however, manufacturers and processors still have the opportunity to search for alternative methods of inhibiting milk microorganisms. In particular, a promising way of using preservatives in the dairy industry in order to significantly reduce the level of microorganisms in food and prevent surface spoilage is the introduction of antimicrobial substances into packaging materials (film), in particular, nanosilver. A prerequisite for this is the safety and environmental friendliness of the packaging itself $[10$, $11,15]$. Research in this direction is being carried out extremely intensively.

However, current evidence suggests that nano silver is far from safe. In this regard, considerable efforts are being made to assess the risks associated with the migration of nano silver and other nano materials from packaging to food products and to develop methods for its detection in food matrices [7]. In the Russian Federation, normative documents have been developed that regulate the process of assessing the migration degree of nanoparticles from packaging to food products.

\section{Materials and Methods}

In this work, studies have been carried out on the effect of silver and zinc oxide microparticles in plastic packaging on the milk composition and microorganisms' development in it, as well as the residual concentrations of these chemicals in the product. In this work, a special preservative additive "EKOS-1" was introduced into the composition of the polyethylene film [1, 4, 6, 19, 20]. Zinc and silver compounds are used as active ingredients in the composition of the additive. The packaging film was obtained by extrusion of high-pressure polyethylene with $1 \%$ preservative addition. The elements' content in the film: silver $-38 \mathrm{mg} / \mathrm{kg}$, zinc $-1020 \mathrm{mg} / \mathrm{kg}$.

To study the influence of electromagnetic radiation and preservatives on the quality and safety of milk, studies were carried out in the conditions of "Lesnye Polyany" stud farm in the Moscow region, as well as the laboratory of selection control of milk quality at the Department of Dairy and Beef Cattle Breeding, Russian State Agricultural University named after K.A. Timiryazev.

Physicochemical, microbiological and technological indicators of milk and dairy products were studied by traditional arbitration methods, as well as on milk quality analyzers.

In this work, an electromagnetic pulse generator was used for milk processing, which creates an alternating magnetic field with the required parameters in the solenoid. The structure of the device includes the actual generator of current pulses, as well as replaceable emitters-solenoids. When the generator is operating, an electromagnetic field of $50 \mathrm{~Hz}$ industrial frequency is created both inside its solenoid and around it. The solenoid has a 
resistance $\mathrm{R}=2.0 \mathrm{Ohm}$, inductance $\mathrm{L}=12.93 \mathrm{mH}$, and the field strength inside the magnetic coil at a current of $1 \mathrm{~A}$ is $7.61 \mathrm{mT}$. To study the effect, milk is poured into a container placed inside the solenoid. The parameters are set on the device (exposure time, duration of pulses and pauses, pulse voltage) and current pulses begin to arrive at the solenoid, which ensures the creation of an alternating electromagnetic field in the milkreceiving tank. The duration of the electromagnetic effect in the studies was 10 minutes. Control and experimental samples were stored at temperatures of 10,24 and $37^{\circ} \mathrm{C}$. The studied parameters of milk were evaluated after 12, 24 hours of storage.

\section{Results and Discussion}

In the course of milk storage, a number of multidirectional biochemical reactions take place, which are caused by the action of bacterial enzyme systems, as well as metabolic activity products of microorganisms of various groups. Thus, the main physical and chemical parameters change and the organoleptic qualities of milk are transformed. Under the influence of native and bacterial enzymes, milk proteins are denatured with the formation of a wide range of nitrogenous compounds. It is the modification of individual protein fractions during storage of milk, changes in whey proteins and proteins of the fat globule membranes that are of deep scientific and practical interest.

Table 1 shows the values for the protein content in milk under the effect of electromagnetic radiation with exposure time of 10 minutes during storage.

At a temperature of $10^{\circ} \mathrm{C}$, the mass fraction of protein is slightly increased: in experimental samples with EMR - by $0.05 \%$ after 12 hours and by $0.11 \%$ after a day of storage, which is a statistically significant difference. Thus, under the studied storage parameters $\left(\mathrm{T}=10^{\circ} \mathrm{C}\right)$, electromagnetic treatment had an insignificant effect on the protein content in milk; however, a regular increase in this indicator was observed in the experimental samples in comparison with the control.

The most significant changes in the milk protein content occurred during storage at temperatures of 24 and $37^{\circ} \mathrm{C}$. In addition, it should be noted that there is a similar trend in the main milk components' change at the studied storage temperatures.

Table 1. Protein content in milk under EMR exposure at different storage temperatures, \%.

\begin{tabular}{|c|c|c|c|c|}
\hline \multicolumn{3}{|c|}{ Milk with no treatment } & \multicolumn{2}{|c|}{ EMR-treated milk } \\
\hline \multicolumn{5}{|c|}{ Storage duration, hours } \\
\hline $\begin{array}{c}\text { At the } \\
\text { beginning of } \\
\text { the experiment }\end{array}$ & 12 & 24 & 12 & 24 \\
\hline \multicolumn{5}{|c|}{ storage t $10^{\circ} \mathrm{C}$} \\
\hline $3.18 \pm 0.015^{* *}$ & $3.18 \pm 0.011$ & $3.20 \pm 0.021 * *$ & $3.23 \pm 0.013$ & $3.31 \pm 0.012 *$ \\
\hline \multicolumn{5}{|c|}{ storage t $24^{\circ} \mathrm{C}$} \\
\hline $3.18 \pm 0.015$ & $3.29 \pm 0.021$ & $3.46 \pm 0.01$ & $3.29 \pm 0.024$ & $3.49 \pm 0.009$ \\
\hline \multicolumn{5}{|c|}{ storage t $37^{\circ} \mathrm{C}$} \\
\hline $3.18 \pm 0.015^{*}$ & $3.29 \pm 0.041$ & $3.51 \pm 0.032 *$ & $3.41 \pm 0.054$ & $3.69 \pm 0.044^{*}$ \\
\hline
\end{tabular}

$* \mathrm{P} \geq 0.95 ; * * \mathrm{P} \geq 0.99$

The results obtained confirm the directed effect of time, storage temperature and various parameters of electromagnetic processing on milk proteins. During storage, the protein composition of milk undergoes serious transformations, which affects milk processing and 
its technological parameters. The longer the storage, the deeper and wider the qualitative change in the product.

Table 2 contains data on the total number of bacteria, the amount of lactic acid bacteria, yeast and molds in the studied milk 12 and 24 hours after EMR exposure (exposure time 10 minutes).

It was found that the studied electromagnetic treatment parameters influenced the change in QMAFAnM, the amount of LAB, the level of yeast and mold fungi. So, at a storage temperature of $10^{\circ} \mathrm{C}$, the total milk bacterial load one day after 10 minutes of EMR was $1.4 \times 10^{5} \mathrm{CFU} / \mathrm{ml}$. The amount of yeast and mold fungi in the test samples was markedly reduced: after 12 and 24 hours of storage, the number of yeast cells in milk was $0.2 \times 10^{1}$ and $1.2 \times 10^{1} \mathrm{CFU} / \mathrm{ml}$, respectively. The electromagnetic milk radiation had an insignificant effect on the amount of lactic acid bacteria at $10^{\circ} \mathrm{C}$ storage temperature. The most optimal temperature regime of $24^{\circ} \mathrm{C}$ for the group of mesophilic bacteria had a significant effect.

Treatment with electromagnetic radiation for 10 minutes affected the development of yeast, mold fungi and lactic acid bacteria. After 24 hours of milk storage $\left(\mathrm{t}=24^{\circ} \mathrm{C}\right)$, the $\mathrm{LAB}$ amount in the control sample was found at the level of $2.3 \times 10^{4} \mathrm{CFU} / \mathrm{ml}$, while in the experimental (EMR 10 minutes) this indicator decreased and amounted to $2.0 \times 10^{4}$ $\mathrm{CFU} / \mathrm{ml}$.

Table 2. Microbiological indicators of milk under EMR influence at different storage temperatures.

\begin{tabular}{|c|c|c|c|c|c|}
\hline \multirow{3}{*}{ Indicator } & \multicolumn{3}{|c|}{ Milk with no treatment } & \multicolumn{2}{|c|}{ EMR-treated milk } \\
\hline & \multicolumn{5}{|c|}{ Storage duration, hours } \\
\hline & $\begin{array}{l}\text { Before } \\
\text { storage }\end{array}$ & 12 & 24 & 12 & 24 \\
\hline \multicolumn{6}{|c|}{ storage $\mathrm{t} 10^{\circ} \mathrm{C}$} \\
\hline QMAFAnM, CFU/ml & $4.4 \times 10^{3}$ & $6.4 \times 10^{4}$ & $2.3 \times 10^{5}$ & $3.8 \times 10^{4}$ & $1.4 \times 10^{5}$ \\
\hline $\mathrm{LAB}, \mathrm{CFU} / \mathrm{ml}$ & $1.4 \times 10^{2}$ & $1.9 \times 10^{2}$ & $7.3 \times 10^{2}$ & $1.8 \times 10^{2}$ & $6.9 \times 10^{2}$ \\
\hline $\begin{array}{l}\text { Yeast and mold fungi, } \\
\text { CFU/ml }\end{array}$ & $5.9 \times 10^{1}$ & $6.1 \times 10^{1}$ & $9.0 \times 10^{1}$ & $0.2 \times 10^{1}$ & $1.2 \times 10^{1}$ \\
\hline \multicolumn{6}{|c|}{ storage t $24^{\circ} \mathrm{C}$} \\
\hline QMAFAnM, CFU/ml & $4.4 \times 10^{3}$ & $2.2 \times 10^{5}$ & $4.5 \times 10^{6}$ & $2.0 \times 10^{5}$ & $3.2 \times 10^{6}$ \\
\hline $\mathrm{LAB}, \mathrm{CFU} / \mathrm{ml}$ & $1.4 \times 10^{2}$ & $2.6 \times 10^{3}$ & $2.3 \times 10^{4}$ & $2.2 \times 10^{3}$ & $2.0 \times 10^{4}$ \\
\hline $\begin{array}{l}\text { Yeast and mold fungi, } \\
\text { CFU/ml }\end{array}$ & $5.9 \times 10^{1}$ & $1.9 \times 10^{2}$ & $5.1 \times 10^{2}$ & $1.0 \times 10^{2}$ & $1.2 \times 10^{2}$ \\
\hline \multicolumn{6}{|c|}{ storage t $37^{\circ} \mathrm{C}$} \\
\hline QMAFAnM, CFU/ml & $4.4 \times 10^{3}$ & $6.4 \times 10^{5}$ & $2.5 \times 10^{7}$ & $4.3 \times 10^{5}$ & $0.5 \times 10^{7}$ \\
\hline $\mathrm{LAB}, \mathrm{CFU} / \mathrm{ml}$ & $1.4 \times 10^{2}$ & $1.8 \times 10^{4}$ & $2.3 \times 10^{5}$ & $9.8 \times 10^{3}$ & $0.1 \times 10^{5}$ \\
\hline $\begin{array}{l}\text { Yeast and mold fungi, } \\
\text { CFU/ml }\end{array}$ & $5.9 \times 10^{1}$ & $1.6 \times 10^{2}$ & $1.4 \times 10^{2}$ & $8.9 \times 10^{1}$ & $3.8 \times 10^{1}$ \\
\hline
\end{tabular}

The growth suppression of milk microorganisms after electromagnetic treatment at a storage temperature of $37^{\circ} \mathrm{C}$ was as follows: the QMAFAnM index in the control sample after a day of storage amounted to $2.5 \times 10^{7} \mathrm{CFU} / \mathrm{ml}$, and in the experimental (with 10 minutes of EMR) $-0.5 \times 10^{7} \mathrm{CFU} / \mathrm{ml}$. There was also a change in the amount of LAB in the 
decreasing direction: from $2.3 \times 10^{5} \mathrm{CFU} / \mathrm{ml}$ in the control to $0.1 \times 10^{5} \mathrm{CFU} / \mathrm{ml}$ in the experimental sample.

The study of changes in the chemical and microbiological composition of milk during its storage in a packaging film with a preservative showed that despite the low content of preservative in the surface layer of polyethylene, its effect was quite significant (Table 3). It was found that during storage of milk at a temperature of $10^{\circ} \mathrm{C}$ there was no significant change in the chemical composition and properties of milk regardless of the storage conditions. Indicators such as acidity, content of fat, protein, lactose, dry substances remain unchanged within the experimental error for the source milk aged for 24 hours in glass containers and in contact with modified polyethylene. It is noteworthy that the number of somatic cells also did not change. However, according to the QMAFAnM indicator, milk spoilage occurred both in glass containers and in modified polyethylene. At the same time, according to the QMAFAnM indicator, milk that was stored in polymer packaging with the use of Ecos preservatives had $38 \%$ better performance than milk stored in glass.

Table 3. Chemical and microbiological indicators of samples when stored in various packaging.

\begin{tabular}{|c|c|c|c|}
\hline \multirow{3}{*}{ Indicator } & \multirow{3}{*}{ Source milk } & \multicolumn{2}{|c|}{ Experimental samples } \\
\hline & & Glass package & $\begin{array}{l}\text { In polymer packaging } \\
\text { with Ecos preservative }\end{array}$ \\
\hline & & \multicolumn{2}{|c|}{ Storage temperature $10^{\circ} \mathrm{C}$} \\
\hline Fat, \% & $3.57 \pm 0.08$ & $3.57 \pm 0.08$ & $3.45 \pm 0.07$ \\
\hline Protein, $\%$ & $2.99 \pm 0.06$ & $3.00 \pm 0.08$ & $3.02 \pm 0.08$ \\
\hline Lactose, $\%$ & $4.75 \pm 0.08$ & $4.76 \pm 0.08$ & $4.78 \pm 0.08$ \\
\hline Dry matter (NFMS), $\%$ & $12.3 \pm 0.1$ & $12.3 \pm 0.1$ & $12.2 \pm 0.1$ \\
\hline Acidity, ${ }^{\circ} \mathrm{T}$ & 16 & 16 & 16 \\
\hline $\begin{array}{l}\text { Somatic cells, } \\
\text { thousand } / \mathrm{cm}^{3}\end{array}$ & $134 \pm 6$ & $142 \pm 7$ & $122 \pm 8$ \\
\hline Freezing point, ${ }^{\circ} \mathrm{C}$ & $-0.6 \pm 0.1$ & $-0.6 \pm 0.1$ & $-0.6 \pm 0.1$ \\
\hline \multirow[t]{2}{*}{ QMAFAnM, CFU $/ \mathrm{cm}^{3}$} & 230000 & 880000 & 540000 \\
\hline & & \multicolumn{2}{|c|}{ Storage temperature $24^{\circ} \mathrm{C}$} \\
\hline Fat, \% & $3.57 \pm 0.08$ & $3.62 \pm 0.08$ & $3.44 \pm 0.09$ \\
\hline Protein, $\%$ & $2.99 \pm 0.06$ & $3.19 \pm 0.09$ & $3.10 \pm 0.08$ \\
\hline Lactose, $\%$ & $4.75 \pm 0.08$ & $4.55 \pm 0.08$ & $4.67 \pm 0.09$ \\
\hline Dry matter, $\%$ & $12.3 \pm 0.1$ & $12.3 \pm 0.1$ & $12.3 \pm 0.1$ \\
\hline Acidity, ${ }^{\circ} \mathrm{T}$ & 16 & 30 & 23 \\
\hline $\begin{array}{ll}\begin{array}{l}\text { Somatic } \\
\text { thousand } / \mathrm{cm}^{3}\end{array} & \text { cells, }\end{array}$ & $134 \pm 6$ & $148 \pm 6$ & $131 \pm 6$ \\
\hline Freezing point, ${ }^{\circ} \mathrm{C}$ & $-0.6 \pm 0.1$ & $-0.6 \pm 0.1$ & $-0.6 \pm 0.1$ \\
\hline QMAFAnM, CFU $/ \mathrm{cm}^{3}$ & 230000 & 8100000 & 1400000 \\
\hline
\end{tabular}

When storing milk for a day at $\mathrm{t}=24{ }^{\circ} \mathrm{C}$, large changes in chemical parameters and the QMAFAnM index were observed. In a milk sample stored in a glass container, the number of bacteria increased to $8.1 \times 10^{6} \mathrm{CFU} / \mathrm{cm}^{3}$ in a day, while this indicator was 6 times less in a package with Ecos. The milk acidity in glass packaging has almost doubled, while in modified polyethylene - only 1.5 times. At the same time, the content of fat, protein, lactose, dry substances remain unchanged within the experimental error for the source milk aged for 24 hours in a glass container and in contact with modified polyethylene. Thus, 
modified polyethylene can significantly slow down its spoilage without changing the main milk characteristics.

\section{Conclusion}

The main economic and technological indicator of milk is its quality, which includes the properties of the product that ensure safety, healthiness, and taste and requires the fullest satisfaction of human needs. Indicators of milk reliability and safety are its safety indicators.

Quality and safety are interdependent, inextricably linked and are mandatory for every dairy product. But they are subject to continuous change under the influence of several factors, one of which is the presence of inhibitory substances in milk. Significant changes are observed during milk storage; depending on environmental conditions, they proceed at an unequal rate and can lead to a decrease in the nutritional value of milk. This is firstly influenced by its chemical composition and storage parameters.

Thus, in order to improve the quality and safety of milk, it is recommended to process it with electromagnetic radiation. Milk storage must be carried out in packaging based on polymers with the addition of Ecos preservatives. When using these methods, it is important to guarantee the safety and full-value of milk, primarily proteins, lactose, fats, vitamins, macro- and microelements.

For food products, there is a complete ban on the presence of any preservatives; in this regard, one of the study objectives was to assess the residual amounts of zinc and silver of modified Ecos polyethylene in milk. An insignificant content of substances included in the package was revealed, i.e., the level of zinc and silver in milk does not exceed the maximum permissible level, which confirms the safety of the studied products.

Based on the complex studies' results, it can be concluded that storing milk in polymer packaging with the addition of Ecos preservatives improves product safety by reducing the number of microorganisms, does not affect the component composition of milk and does not distort the quality and safety indicators of dairy products.

\section{References}

1. I.V. Gmoshinsky, V.A. Shipelin, S.A. Khotimchenko, Health risk analysis, 4, 134-142 (2018)

2. G. Kilvain, Guide to dairy and milk hygiene, 205 (1980)

3. A. Kurak, Livestock of Russia, 21 - 25 (2015)

4. D.M. Myalenko, O.B. Fedotov, Dairy industry, 1, 8-9 (2013)

5. A.P. Olesyuk, Quality and safety of milk and dairy products depending on microorganism inhibitors: Diss. cand. biol. Sciences, 164 (2019)

6. K.I. Popov, A.N. Filippov, S.A. Khurshudyan, Russian Chemical Journal, 53(2), 86-97 (2009)

7. Resolution of the Chief State Sanitary Doctor of the Russian Federation dated July 23, 2007 №. 54 "On supervision of products obtained by using nanotechnologies and containing nanomaterials".

8. The procedure and methods for monitoring the migration of nanoparticles from packaging materials. Methodical instructions (MI 1.2.2637-10), 35 (2010) 
9. G.V. Rodionov, G.V. Organization of production quality control of raw milk, 156 (2009)

10. O.B. Fedotova, A pack milk and dairy products. Quality and safety, 96 (2007)

11. O.B. Fedotova, D.M. Myalenko, Milk processing, 12(206), 54-57 (2016)

12. D.W. Allen, Project Review Meeting of the MAFF Working Party: Chemical Contaminants from Food Contact Materials, 3, 5 - 6 (1999)

13. F. Benhacine, Polymer-Plastics Technology and Materials, 58(3), 328-340 (2019)

14. S.K. Krol, BioMed Research International, 43, 1-11 (2015)

15. B. Green, Journal of Chemical Education, 84(12), 11-19 (2007)

16. E. Peñas, Int. Dairy J., 16, 831-839 (2006)

17. G.V. Rodionov, Bulletin of TAA, $163-172$ (2013)

18. B. Sanchez, Int. J. Dairy Technol., 62, 472 - 483 (2009)

19. M.S. Sarwar, Carbohydrate Polymers, 184, 453-464 (2018)

20. T. Vasiljevic, Int. Dairy J., 18, $714-728$ (2008) 